\title{
Politics of indifference: The case of Nigeria
}

\author{
Felix Chukwudi Onyemachi
}

\author{
Department of Philosophy, University of Calabar, Calabar, Cross River State, Nigeria. \\ Email: onyemachifelix@gmail.com
}

Copyright (@) 2020 Muhammad. This article remains permanently open access under the terms of the Creative Commons Attribution License 4.0, which permits unrestricted use, distribution, and reproduction in any medium, provided the original work is properly cited.

Received 3rd November, 2020; Accepted 7th December, 2020

\begin{abstract}
The paper aims at exposing the deep-rooted phenomenal issue of politics of indifference in the Nigerian state. The paper makes conceptual analyses of politics, indifference and politics of indifference. The paper also examines the politics of indifference in Nigeria, and identifies it as a cog in the wheel of the nation's social, economic, political and infrastructural developments. The paper argues that Nigeria will not have the desired all-round development if the politics of indifference that segregates rather than aggregates is not dissipated. The paper, therefore, concludes that a holistic growth in all spheres of the nation's existence will be realized in the federal, state, and local levels when the 'we-them' mindset that dissociates rather than associates is expunged in Nigeria. The paper employs the method of textual and contextual analyses. The procedure is essentially, expository, critical, analytical and speculative.
\end{abstract}

Keywords: Indifference, inclusive politics, politics, politics of indifference.

\section{INTRODUCTION}

Anyone familiar with Nigeria's politics cannot but conclude that Nigeria is not true to its democratic governance. Politics which ideally should be in the interest of the nationals irrespective of the political party, ethnic group or geopolitical zone that produces leadership is far from being the case in Nigeria. It is a truism that good leadership involves the capacity and ability to respond adequately to issues of national interest. But, in Nigeria, the case is different as politics and its leadership is skewed towards favouring the party, ethnic group or geopolitical zone in power with total disinterestedness in the groups that are considered the 'others'.

The desire of the nation to have a holistic development has been elusive as a result of the lop-sided attention given to some zones or groups that are parts of the unit of Nigeria. Today, only the group that is opportune to hold and control power enjoys the national dividends more than other groups of different political party, ethnic or geopolitical extractions. This informs the exclusive developments in social, educational, political, economic, infrastructural and core basic amenities in the nation given the fact that selected groups enjoy national presence at the neglect of other groups with whom they have equal rights in the nation. Expectedly, agitations and protests from the groups sidelined in the scheme of things as well as denied national relevance abound. The narrative is political instability, social crises, and the move for secession. The thrust of the matter is: where does Nigeria go from here? The situation that threw up people like Adaka Boro, Ken Saro-Wiwa, Nnamdi Kanu, and others is still very much with Nigeria. This has not only contradicted the oneness we profess in the nation, but, also, grossly affected the nation socially, politically, economically and so on, leading the nation to near disintegration.

The politics of indifference is so deep-rooted in Nigeria's leadership so much so that it has become so worrisome as it poses serious threats to the unity and well-being of the nation. Bedeviled by this lack of feelings for and interest in 'others' outside one's enclave, Nigerian leaders and office holders have not only polarized the nation, but, also, by their actions instituted the 'winner-takes-all' leadership mindset. A scenario that necessitated the idea of voting no longer for credible and competent leadership, but based on ethnic, party or geopolitical lines.

It is, therefore, this menace that has rocked the wave of unity in the nation that this paper aims at bringing to the fore its ravaging effects in Nigeria. This is done with the sole aim of advancing an inclusive politics geared towards carrying everyone along regardless of any societal affiliation or distinguishing characteristics to build a 
formidable nation that is 'Nigerian' as citizens pledged.

\section{EXPLICATION OF CONCEPTS: POLITICS}

According to Collins dictionary, "politics are the actions or activities concerned with achieving and using power in a country or society" (Cobuild, n.d). The above definition lacks clarity as politics is only concerned with the use of power but it does not clarify whether the power can be used at one's will and for selfish end or for the common good of the people. The Greek philosophers on the other hand considered politics as dealing with all the activities and affairs of the city state. Politics for them is an allinclusive term that makes no distinction between the state and the government. For them, it is the total study of man, society, morality, state, and so on. Hence, politics is not restricted to mere institution of governance, but, also, a mechanism for achieving societal goals. It is a societal platform which advances the promotion of good living and orderliness for the purpose of achieving a healthy and sustainable society.

\section{Indifference}

According to online dictionary, indifference simply means "lack of interest or concern" (https://www.dictionary.com/ browse/indifference). This implies the act of disinterestedness in things one considers irrelevant so long as it does not affect one. It is the trait of lacking interest, sympathy or concern to things or conditions that ordinarily under normal circumstances should have been given attention to; hence, disinterestedness in or lack of feeling for things.

\section{Politics of indifference}

Politics of indifference would mean an attitude of disinterestedness or lack of feelings among the political leaders, elites and office holders for things or conditions that should have received a comprehensive or holistic attention to. It equally evokes an attitude of neutrality deemed inappropriate to the sphere of political action.

\section{Politics of indifference in Nigeria}

As a matter of optimism, Nigeria has been ravaged by the deadly and disuniting politics of indifference in its manner of politicking. This mannerism has grossly posed serious challenges as it hinders leadership and national growth. Abiola (2008) corroborated the above when he made the point that, "Leadership in Nigeria is constantly becoming more of a problem. Those in the position of power are failing Nigerians every day because they are not responding to challenges of leadership in complex situations" (Abiola, 2008). Abiola may not be far from the truth when one considers how the elected and appointed leaders skew leadership only to favour their in-groups at the expense of the 'external others'. Nigerian leaders seem to have feelings for what concerns them, their party, ethnic groups and geopolitical zones while showing less concern to the good of the citizens that gave them mandates. As a result, "Nigeria's political leadership has been challenged as the common good is sacrificed at the altar of absolute possessiveness and exclusiveness" (Onyemachi, 2020a: 94). It is not unconnected with the above claim when Ucheaga (2009:115) made the point that, "it appears that the unequal distribution favours the already advantaged groups, particularly the North that has dominated power since independence. This constitutes the heart and substance of minority agitation". A critical study over the thrust of agitations of some ethnic, geopolitical and party groups in the nation reveals that, it is either that the agitating groups are not getting enough from the common wealth like others or that they are having little or no federal presence in their groups. This contradicts the federal character principle which directs that "the composition of the federal government or any of its agencies and conduct of their affairs shall be carried out in such manner as to recognize the federal character of Nigeria and the need to promote national unity and command national loyalty. Accordingly, the predominance in that government or its agencies of persons from a few ethnic or other sectional groups shall be avoided" (Constitution of the Federal Republic of Nigeria, Section 8:1b, 1999 Nigerian Constitution).

In principle, the federal character emphasizes the need to manage the affairs of the nation with equal and fair representation of all states that give voices to their ethnic groups. Regrettably, lack of interest of those in the helm of affairs towards the considered outgroups has without doubt, raised dust in the nation. More disturbing is the attitude of the political leaders that not only ignore those outside their ethnic groups and political parties, but, also, the entire good of the nation. It is against this scenario that Ndibe (2003:51) bemoaned that, "Nigeria sadly has not had the luck of being governed by a leader; a leader who eats while his followers starve, who flies abroad in a plush private jet for medical check-ups while millions of fellow citizens are decimated by diseases, who secures his property with armed police and soldiers while leaving public property to be ravaged by arsonists.... Such a leader is anathema". Nigerian leaders appear to be more concerned with what affects them, their cronies, and ingroups with total disregard to the social, economic, and infrastructural needs of others. This has questioned the unity which the nation professes as the opposite is the case.

In the sector of infrastructure, some groups that share the same citizenship with other groups in the nation appear to be receiving more national attention than the others. This underdevelopment of infrastructure in the neglected 
zones or groups, and the neglect to cater for their necessities of life have resulted in a growing disaffection and serious tension. Communal clashes, religious riots, militancy and other societal unrest such as the recent clash between the Birom and the Hausa community in Jos, the Ogoni people and other communities, mostly from Delta, Rivers, Bayelsa, and Akwa Ibom States in collaboration with ethnic militias and organizations have become vocal and agitating over their dissatisfaction about official disregard to their well-being (Ali, 2013). Considering the case of neglect in view, it is so glaring that Nigeria's politics is a contradiction given the fact that the nation is doing the opposite of the ideal purpose for politics which is meant to better the lots of the citizenry with no differentiating mechanism.

The social sector of the nation has its share of the politics of indifference in Nigeria. The core ingredients of social equality have been thrown overboard as fairness in distribution, treating people with equal concern and respect, and equality of opportunity has eluded the nation. According to Alumona et al. (n.d), "It is within the above context that we can locate separatist agitations among the Igbo ethnic group in the Southeast, Nigeria. The existence of separatist movements such as the Movement for the Actualization of the Sovereign State of Biafra (MASSOB), Biafra Zonist Movement (BZM) and the Indigenous People of Biafra (IPOB) all point to the perceived feelings of indifferent attitude of the Igbo" (Alumona et al., n.d). Though, a particular ethnic group is used as a case in point, other groups like Movement for Emancipation of Niger Delta (MEND), Oduduwa People's Congress (OPC), and so on, have a fair share of this alienating politics of indifference in Nigeria.

Still on the social realm, women and youths are not left out in this politics of indifference as they do not get commensurate considerations in the scheme of things. They feel neglected in Nigeria's leadership. More worrisome is that lack of gender parity has been the order of the day so much so that the quota of political space for women is far from being inclusive in Nigeria. One may argue that women are not naturally central to strong thinking. But, when one considers the role of women in Nigeria in the parastatals, offices, political parties, constituency representations, and so on, one would readily submit that women have no limit to what they can offer in the nation. The likes of Margaret Ekpo, Gambo Sawaba, Funmilayo Ransome Kuti who excelled in their different places of engagements, and other outstanding contemporary political juggernauts serving as Ministers, and representing their constituencies in the National Assembly and other privileged positions in the federal, state and local levels are pure indications that if maximally included in the scheme of things without bias, women will perform. But, unfortunately, women are yet to find a considerable space in Nigeria's leadership given today's party politics that seems transactional where fundamental rights of some groups like women and those in the minority are bound to be abused. It is against this politics which undervalues the women folk that Obiliki (2020) laments: "Despite the gains made in some parts, women remain disadvantaged in terms of basic human rights, access to economic opportunities, access to resources, justice on gender-based violence, and importantly in the wielding of political power".

Economically, the nation bedeviled by this polarizing politics of indifference has not been fair to all the groups. So, disheartening that some groups enjoy the wealth that accrues from the national and natural resources while others are treated like strangers in their land. This has made Nigerians suffer setbacks in their economic output as a result of the actions of the disregarded groups over government property. This is because those whose land produces these natural resources that feed the nation are the ones suffering the scourges of hunger, ecological disaster and diseases, underdevelopment, death of human, aquatic and wild lives, while the groups regarded as first-class citizens are enjoying the common wealth. It was in this connection that Saro-Wiwa (1995) decried: "The state of the road irked me. It was one of my overriding concerns. Not the road itself, but the fact that in this rich, oil-bearing area, the roads should be so rickety, while in the north of Nigeria, in that arid part of the country, there were wide express ways constructed at great cost with the petrodollars which the Delta belched forth. The above is a reflection of gross injustice as some parts of the nation receive more national dividends at the expense of the parts that are majorly producing the resources that boost the nation's economy. The regions whose land produce the resources that feed the nation, sit on abundance but wallow in abject poverty. This accounts for the rate of underdevelopment in some parts of the country especially the oil-producing region of Niger Delta.

Consequent upon the devastating effects of the politics of indifference in Nigeria, the nation is yet to experience all-round development. Although Nigeria is the fourth oilproducing country in the world, it is still dependent on other nations for survival even after gaining her independence since 1960. Hence, until Nigeria eschews the divisive politics of indifference, and embraces leadership mechanism that aggregates rather than segregates, the nation will remain a perpetual stranger to good governance.

\section{INCLUSIVE POLITICS: THE WAY OUT}

Inclusiveness is ideally the quality of including different types of people in their differences and treating them all fairly and equally (https://dictionary.cambridge.org). This equally implies a sense of including someone or group in a larger group or set. This, in practical terms would mean that what one uses in the realization of a set goal, objective or interest for one's group should not be at variance with one's commitment to the ideals of humanity. Inclusive 
politics is the idea of working with as well as carrying everyone along in the actualization of a set goal in society irrespective of party, ethnic group or geopolitical differences. It is in this connection that Onyemachi (2020b:78) made the point that "a society realizes its set goals and objectives when all human and material resources are complementarily harnessed". Therefore, inclusive politics is devoid of one-sidedness, discrimination, segregation, divisiveness, and all forms of alienation in society. Thus, it is a holistic approach that accounts for the social, political, economic and developmental wellbeing of the nation.

Political inclusiveness is so vital to sustainable democracy. It is "the idea that every citizen, regardless of class, age, gender, sexual orientation, ability, group, culture and ethnic or religious background, should have an equal right and opportunity to engage with and contribute to the functioning of the institutions and processes" (Cordenillo, 2018). This implies that in the political decision making and processes, no voice should be left unheard; no one should be sidelined; no one should be subjected to any form of exclusionary rhetoric. Every citizen is expected to be allowed to participate and represent his or her interest and the interest of those he or she stands for because, according to United Nations Development Programme (n.d), "societies whose political institutions are more inclusive and participatory tend to be more peaceful and resilient, just as societies practising exclusion tend to be more vulnerable to fragility and conflict". Therefore, political inclusiveness will not only remedy structural inequality in Nigeria, but also serve as a necessary tool to sustaining peace as well as preventing conflict in the nation.

Economic inclusiveness on its part considers the worseoff individuals, groups and regions. According to Duran (2015), economic inclusiveness "is not only about expanding national economies but also about ensuring that the most vulnerable people of societies are reached. The equality of opportunity and participation in growth by all". This by extension, therefore, entails creating employment opportunities to regions that are impoverished by building firms and industries that will manifest the presence of government as well as incorporating all groups or regions in economic matters through equal representation, and allowing each group to enjoy the benefits of the nation's economy.

Similarly, inclusive development takes into consideration all the individuals, groups and regions' well-being. "Inclusive development consists of ensuring that all the marginalized and excluded groups or regions are made stakeholders in development the process". This implies that no group should suffer exclusion from national development on the grounds of gender, age, party, or ethnic inclination. Therefore, any development found in group 'A' should also be found in group 'B'. No one or group should be left behind in the development processes. Rather, everyone and group, because of the brotherhood in nationhood, should be carried along. This will be the case when the leadership of Nigeria would begin to see beyond every regional or ethnic microcosm as to transcend to ensuring indiscriminate development in all facets of national and human existences. It is only when every group is equally treated in social, political, economic, environmental and other matters of national relevance that one would say there is inclusive development in the Nigerian state; because, "a society that treats all its members as equals, the varied realms of social, economic, political and cultural will work in synergy for the good of all" (Oluwagbemi-Jacob 189). Consequently, equality of opportunity, fairness in distribution, respect for all regardless of one's cleavage, and treating everyone with equal concern are of utmost importance. Inclusive development, therefore, is geared towards achieving inclusive society, valuing diversity as well as accommodating differences.

From the foregoing, therefore, inclusive politics abhors the politics of indifference which has bedevilled Nigeria. It negates discrimination, exclusion, segregation, division and all forms of one-sided approach that conduce to the neglect of one or some groups or regions in favour of another group relative to the group or region that produces leadership. It advocates all-round politicking that places value on every citizen regardless of group identity. It equally advances the need for those in the helm of affairs to look beyond their ethnic, party or geopolitical zones in the realization of the national goal. Hence, it is an opportunity for one to be something different but to be everything excellent towards the realization of the nation's common good.

\section{CONCLUSION}

The paper set out to expose the politics of indifference in Nigeria. Upon examination, the paper identified it as a cog in the wheel of the nation's development as it has necessitated a steady decline in Nigeria's social, economic, political and infrastructural well-being. The paper equally argued that Nigeria will make no headway in all-round development if the politics of indifference is not abrogated. The paper concluded that the nation blessed with humongous natural resources will experience a holistic growth in all spheres of her existence in federal, state and local levels when the dichotomizing 'we-them' mindset that disunites rather than unites is dissipated.

\section{CONFLICT OF INTEREST}

The author declares no conflict of interest.

\section{REFERENCES}

Abiola, K. (2008). The psyche of leadership in Nigeria. Nigeria 
World. Retrieved 24-6-2020 from https://nigeriaworld.com/ articles/2008/may/275.html.

Ali, D. A (2013). Leadership and socio-economic challenges in Nigeria. Singaporean Journal of Business Economics and Management Studies, 1(9), 1-8.

Alumona, I. M., Azom, S. N., \& Iloh, E. C. (n.d). The Nigerian State and the Resurgence of Separatist Agitations: The case of Biafra. Retrieved from https://media.africaportal.org/documents/The-Case-ofbiafra.pdf.

Cobuild, C. (n.d). Definition of 'politics'. Collins English Dictionary. Retrieved 26th June, 2020 from https://www.collinsdictionary.com/dictionary/english/politics.

Constitution of the Federal Republic of Nigeria (1999). Lagos: Federal Government Press.

Cordenillo, R. (2018). Political inclusion is vital to sustainable democracy. Retrieved 20th June, 2020 from https://www.idea.int/news-media/news/political-inclusion-vitalsustainable-democracy.

Duran, P. (2015). What does inclusive economic growth actually mean in practice? Retrieved 20th June, 2020 from https://www.undp.org/content/undp/en/home/blog/2015/7/31/ What-does-inclusive-economic-growth-actually-mean-inpractice-

.html\#: :text=Inclusive\%20growth\%20is\%20about\%20ensuri ng,including\%20the\%20most\%20vulnerable\%20members. https://dictionary.cambridge.org/.

https://www.dictionary.com/browse/indifference.
Ndibe, O. (2003). Pounded yam politics. The Guardian Newspaper. p 51. Published 15th March, 2015.

Obiliki, N. (2020). Ideas for a new Nigeria: Why we should all push for women inclusion in governance. Retrieved 20th July, 2020 from https://businessday.ng/columnist/article/ideas-fora-new-nigeria-why-we-should-all-push-for-women-inclusionin-governance/.

Oluwagbemi-Jacob, D. (2018). The matter of justice and equity in Nigeria: A reflection on M. Chris Alli. The Federal Republic of Nigerian Army Symposium on Sage Philosophy. Maduabuchi D. (ed.). Lagos: Malthouse Press Limited.

Onyemachi, F. C. (2020a). The Principle of common good in Ibuanyidanda philosophy and egocentrism in Nigeria's political leadership. Pinisi Discretion Review, 4(1), 93-102.

Onyemachi, F. C. (2020b). Complementary Leadership: A neglected key to national security issues in Nigeria. GNOSI: An Interdisciplinary Journal of Human Theory and Praxis, 3(1), 76-84.

Saro-Wiwa, K. (1995) A month and a day: A detention diary. Ibadan: Spectrum Books Limited.

Ucheaga, D. (2009). Sustainable development and the ethnic minority question in Nigeria. ABIBISAM: Journal of African Culture and Civilization, 2, 107-124.

United Nations Development Programme. (n.d). Democratic governance and peace building. Retrieved 20th June, 2020 from https://www.africa.undp.org/content/rba/en/home/ democratic-governance-and-peacebuilding.html. 